\title{
Social Network Harmonization and Public Service A Case Study of Boalemo, Indonesia
}

\author{
Ismet Sulila \\ Department of Public Administration, \\ Universitas Negeri Gorontalo, \\ Gorontalo, Indonesia \\ ismet.sulila@gmail.com
}

\begin{abstract}
This second-year research is the continuation of the previous research regarding the social situation on the pluralism in the district of Boalemo. The results of the initial year study consist of: 1) the social interaction, social mapping, and the social networking in Boalemo, 2) the contributing and inhibiting factors of the harmonization of social network in Boalemo. According to the initial year result, the focus of this second-year research is on how to achieve the harmonization of social network in Boalemo by considering the contributing and inhibiting factors, and how the model of harmonization of social network can be able to support the public service in Boalemo. The research method is qualitative descriptive method, starting from data collection, data reduction, data display, and conclusion. The result shows that: 1) all three contributing factors can be applied simultaneously through the implementation concept of social networking. 2) The harmonization model concept of social networking can be used in any region that has the similar social situation or characteristics with the district of Boalemo, Gorontalo province.
\end{abstract}

Keywords: harmonization; social network; public service

\section{INTRODUCTION}

The implementation of governance during the reformation are full of demands on a more effective and efficient governance. To meet this demand, implementation of governance in the regions have been implemented in more autonomous and more decentralized ways compared to the old centralized paradigm. Within this context, decentralization is popularly defined as delegation of powers and authority from the top management (owner of authority) to the low-level management (implementer). On the other hand, autonomy means independence. The independence in this context refers to freedom to select and implement governance that are in line with the ability to implement the day to day management of the government.

The change of paradigm in government implementation has made local government as the front liner in the implementation of government tasks, especially in public service delivery. Local government are now obligated to provide public services in sectors such as, health, education, and other utilities. For local government to be able to provide these services, conducive situations in the region is required.

Boalemo district is one of the regions with most diverse ethnic compositions, and with its plural community that reflected the diversity of its people's culture and languages. Other than native Gorontalo people, in this area also reside Javanese, Buginese, Balinese, Bajaunese, Minahasanese,

Corresponding author: Ismet Sulila
Sangihenese, Chinese, and Arabic descendants. In addition, there are also social groups that are formed in this district. Currently, there are 33 social groups recorded to exist in this area. These various social groups clearly have their own visions as the aspirations of these groups' members.

The initial year study has revealed that the social networks in Boalemo regency have been formed in several sub-districts based on the interest and demands of the people in that area, either for political interest, economic interests, religious interests, or social interests. Interaction among these social networks in Boalemo regency is implemented through social control in forms of regular meetings and other social activities to discuss the development issues in Boalemo district. In addition, the initial study also revealed that there were several factors that can support the concept of harmonization of social networks in this region, such as: a) kinship, b) government's attention, c) assistance given for social groups. Whereas the factor that may hamper the social network harmonization is the sectoral ego in each region.

\section{A. Social Groups Within Community}

Within social context, it is natural for human being to have to basic desires, to unite with others in his or her environment and to unite with his or her environment [1]. To adjust with both environments, human uses his or her minds, senses, and wills. Several requirements for a social group that can be described as follow, namely 1) each group member has to be aware that he or she is part of that group, 2) there are reciprocal relationship among members, 3) there is a coowned factor, hence it strengthen the relationship, 4) it has structure, norms and has behavior pattern, 5) it has system and process [2]. In this study social network is considered as one of the important things that contribute to the public service delivery in the region. This is because the government will only be able to deliver a good governance when it is supported by conducive society.

In relation to types of social groups, the social groups can vary according to the size of groups, its members, how individuals influence groups and social interaction among member of social groups. Analysis on social groups can be done from the smallest components which consists of one person as the focus of social relationship or between groups. For a community, for instance, consists of units or groups based on area who have specific interests. Association as a comparison is rather formed to fulfil certain interests. In certain context, members of community or association are not aware about common interests. Further, there are also 
classification of social groups based on level of organization. The groups consist of well-organized groups, such as state, to almost unorganized groups.

In addition, social groups, as described above, within the context of social groups is also known as Paguyuban. According to Ferdinand, Tonnies, and Loomies in [1] Paguyuban is a form of common life, where the members are bound with mental relationship that are pure and natural, and ever-lasting. This paguyuban is often found within kinship groups. A paguyuban has several characteristics, as follow: 1) intimate, 3) exclusive. The relationship is only for "us".

In achieving its vision, the Boalemo BERTASBIH (Beriman, Taqwa, Sehat, Bersih, Indah dan Harmonis/believing in one good, pious, healthy, clean, beautiful, and harmonious), the Bupati (head of the district) has provided a space for civil society, where individuals and community groups can interact within the spirit of tolerance. The government of Boalemo allowed different groups of community to exist either based on kinship, faith, interest, professional relationship, nongovernment organization, etc.

The result of the initial year study revealed that interactions among these social groups and factors that support and inhibit the establishment of positive social groups interactions in Boalemo. Based on this initial year's findings, the second-year research focused on formulating social networks harmonization in Boalemo to support the implementation of public service in the district of Boalemo

\section{B. Public Service}

In Indonesia, the concept of government administration service is often used interchangeable with concept of licensing service and public service. These terms often used as the translation of public service. This can be seen in various government documents as used by Ministry of Manpower.

In this study, government administrative service is synonymous with licensing service. While public service is more about services provided for public.

The decree of Minister of State Apparatus Empowerment No. 81 of 1993 which was later improved with decree of Minister of State Apparatus Empowerment No. 63 of 2003 defines public service as:

"all forms of services provided by central, regional, and local government and state owned enterprises in form of services or goods, either fulfilling the community's needs or in fulfilling the requirements stipulated by the laws." [3]

Whereas public is defined as community itself, which should be governed and served by the government as well as leader in state constitution [4]. In addition, public service is also defined as provision of service for individual and community who have needs that can be fulfilled by the organization based on the prevailed rules and regulation [5].

Following those definitions, public service can be defined as all forms of services, either goods and services, whose provisions are government responsibilities, either in central and local level to fulfil government regulations. Whereas, administrative services or licensing services are all forms of services provided for the community where the products are license or documents.

\section{Correlation Between Social Networks and Public Service}

Within the context of this study, social network is viewed as a principal thing that determine and contribute to the public service in the region. This is based on the argument that a conducive and secure social environment will be able to support implementation of a good government. A survey by BPS showed that Boalemo has a population of 109,868 people which consist of various social groups [6]. The newest development is that this region has 33 social groups. This social groups contribute to the development of the region. The challenge here is how to develop government's ability to develop synergy among these social groups to make them able to contribute to the develppment of the region.

In some cases, where social groups have no conducive relationship, they tend to be desctructive to the development of the regions. On other words, harmonization of social networks in the region has to be well-developed in order to contribute to the development and more specifically to the imporvement of public service delivery in the region. Therefore, for Boalemo regency, the challenge is how to harmonized the social networks of these social groups to contribute to the improvement of public service in this regency.

\section{RESEARCH METHOD}

This study uses a qualitative approach to comprehensively study the harmonization of social networks as supporting and inhibiting factors of the public service delivery in Boalemo regency, Gorontalo. The procedure of this study is started from data collection, data reduction, data display, and conclusion drawing as suggested by [7]. In addition, there are also focus group discussion held with key stakeholders in each stage of the study to sharpen its findings. This study is expected to positively contribute to the harmonization of various social networks in Boalemo regency as one of the efforts to improve public service delivery.

The initial step is to conduct observation and initial data collection in the field. The data are related to the focus of this study, harmonization of social networks as supporting factor of public service delivery in Boalemo regency. The data then analyzed to create a model on how to harmonize various social networks in the area.

\section{RESULTS AND DISCUSSION}

The harmonization concept is intended to capture and to create balance and symmetrical relationships among social networks in this regency. These social networks may have different interests. The possibility of conflict of interests is one of the focus in harmonization of these social networks. This is because, the bigger the conflict of interests among different social networks, the bigger the possibility for the horizontal conflicts among these social networks that highly likely to hamper the public service delivery in the region.

Thus, this second-year study is aimed at establishing a model to harmonize social networks in Boalemo regency which is based on the findings of the initial year study on the 
factors that support and inhibit social networks harmonization in this regency.

\section{A. Creating Social Networks Harmonization Based on the Supporting Factors and the Inhibiting Factors}

This study reveals that there are three supporting factors to the harmonization of social networks in Boalemo Regency namely: Kinship. The study reveals that interaction among different members of social networks or organizations which clearly have different objectives happens in family events such as, family meetings, family party, funeral events, etc. Kinship still plays a dominant role in harmonizing these different groups. Kinship bond is still considered something sacred that should be upheld above the organization bond. Thus, members of different social organizations may gather in family events where they put aside their differences and come together as a family. Such kinds of activities outside the social groups activities have become a supporting factor in harmonizing the social networks in this regency. This study recommends that there should be events created to maintain and strengthen this kindship bond.

However, it has to be noted that in such activities, the groups interest should not be discussed, rather, it has to discuss specifically about the kinship relations and things related to familial topics. Therefore, these kinship-based activities should be regularly scheduled through events such as, family gathering or arisan. This arisan concept is aimed to put aside differences among various interests and differences among various social groups. This arisan concept can also strengthen the kinship bonds among family members regardless to their social groups affiliations.

The second supporting factor to the social network harmonization is government attention. Government of Boalemo also pay attentions to the aspirations put forward by various social groups, regardless to whether those aspirations/demands can be fulfilled or not. In addition, the government also put these aspirations into a priority scale and considering the equality aspect in each area of these social groups. This study finds that government agencies should take more active role, especially from various government agencies in hearing and paying attention to the recommendation or aspirations voiced by these social groups.

The concept that would like to be built here is the togetherness between various social groups and government of Boalemo, either the village level government, the sub-district level government, or the regency government, along with its government agencies as one entity that works together to develop their region. For this to happen, local government policy to harmonize these various organization and various level of governments in the region for them to be able to work together in both village and sub-district level. The active role that could be taken by different government agencies in Boalemo, i.e., each government agency takes one village or sub-district as their target area. Thus, the different groups of community in this area will feel that they are noticed by the government. This, in turn, will push, establish, and maintain social harmony in the region.
In relation to various government agencies cooperation with various level of governments. It is important to encourage each of these government agencies to take one area/village as their focus area of assistance. Distribution of assistance area among government agencies is one of governments' attention to encourage and maintain the social networks harmonization in the area.

The final supporting factor is the social groups' coaching. This supporting factor is routinely implemented by the Government of Boalemo through its KESBANGPOL (department of homeland unity and politics) agency. This agency has been routinely held meetings with social organizations in this area. In addition, the meetings also held with each social group to discuss development issues in Boalemo. Through this third supporting factor, where communication and meetings are held regularly between various social groups, horizontal conflicts that may arise among social groups can be minimized.

The conditions described above as factors that supports the harmonization of social networks through assistance provided for social groups in the district are yet to be maximized. Government assistance is still limited to the KESBANGPOL Boalemo. As it has been mentioned above, other government agencies need to take active role in assisting areas/villages in the district as what have been suggested above. This is strongly corelated with the second supporting factor mentioned above, which insists the needs of maximum role of local government, through its agencies, from sub-district level up to the district government level. This should be done in cooperation with other stakeholders outside government. Another important thing to be considered is the cooperation among community, social groups, government, and other parties is the togetherness in planning, implementing, and executing continuous evaluation on harmonization of social networks in this area.

On the other hand, this study also reveals that aside from the horizontal conflict mentioned above, another inhibiting factor is the sectoral ego. Sectoral ego here is the strong pressure from each social group for their aspiration/voice/demands to be heard and fulfilled by the government. This sectoral ego can be curbed through, 1) learning the root of the ego, 2) provide understanding to the groups who have different interests to co-involve in development programs that are transparently managed, hence, made them aware of the resources constraints that made the government of Boalemo has to make priority scale in development, and 3) conduct regular meetings with various social groups to discuss development issues and finding alternatives for the currently faced problems. Through these three things, it is expected that sectoral ego can be minimized and it can instead be used to support the harmonization of social groups in this area.

\section{B. Social Networks Harmonization Model}

This initial and second year study have resulted in the creation of social networks harmonization model which involves government, social groups, and other relevant 
organizations. The model of social networks harmonization can be described by the following figure:

Figure 1. Social Network Harmonization model as Determining Factor in Public Service Delivery

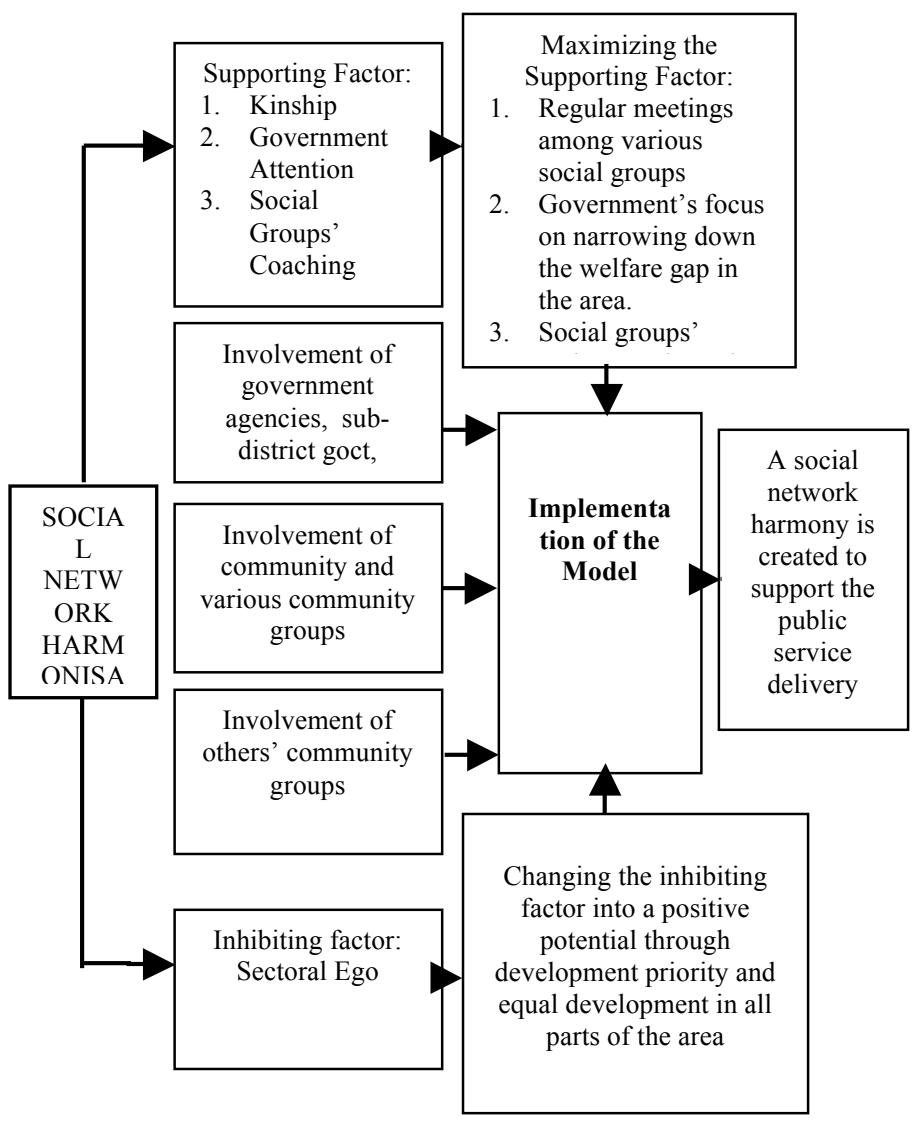

\section{CONCLUSION}

This study concludes that there are several factors that support and inhibit the harmonization of various local groups in Boalemo regency. The supporting factors are kinship, government attention, and social groups' coaching/assistance are the supporting factors for the social networks harmonization in Boalemo Regency, whereas, the sectoral ego is the inhibiting factor. This sectoral is more pronounced when different social groups are trying to make their aspirations heard by the government. This is evident in the existence of various social organizations such as, youth organization, religion-affiliated organization, health organization, education organization, etc. Social networks in this regency are established throughout the area based on the interests and aspiration form that particular area. Interaction of social networks in Boalemo is developed through social control implemented through regular meetings and other social activities to discuss the development issues in Boalemo regency.

This study also provided a social networks harmonization model in Boalemo to increase the public service delivery in this model. Maximizing the supporting factors through regular meeting among various social groups, government's focus on minimizing the welfare gap in the area, and government agencies active involvement in assisting the social groups as shown in the model above is needed

Curbing the sectoral ego as an inhibiting factor and turning it into a positive potential through educating the community groups and involving them in a transparent development process to create their understanding of the limited resources that the government have will also help accelerate the social groups' harmonization to support the public service delivery in the region

Finally, this study also recommends that further study on social networks harmonization concept in this area is still needed as there still a possibility for other supporting and inhibiting factors for social networks harmonization to emerge

\section{ACKNOWLEDGMENT}

The author would like to thank the Research Institution (Lembaga Penelitian) of Universitas Negeri Gorontalo and the Government of Boalemo regency for their supports to this study.

\section{REFERENCES}

1] Basrowi, Introduction to Sociology (Pengantar Sosiologi), Ghalia Indonesia, Bogor, 2005

[2] Soekanto, 2002, Sociology An Introduction (Sosiologi Suatu Pengantar), Rajawali Press

[3] Decree of the Minister of Administrative Reform (Keputusan Menteri Pendayagunaan Aparatur Negara) No. 63 Tahun 2003

[4] I. Kencana, Public Administrative Science (Ilmu Administrasi Publik), Rineka Cipta, Jakarta,1999,

[5] J.Widodo, Good Governance, Insan Cendekia, Surabaya, 2001

[6] S. Nursa, Boalemo Bertasbih, Madani Community Based Development Model , (Boelemo Bertasbih, Model Pembangunan Berbasis Masyarakat) Madani, Forum Media Utama, 2007,

[7] F. Sanafiah, 2005, Social Research Formats (Format-Format Penelitian Sosial), Jakarta: Rajagrafindo Persada. 